\title{
САКРАЛЬНИЙ ПРОСТІР У ДИЛОГІЇ Г. ПАГУТЯК «ПИСАР СХІДНИХ ВОРІТ ПРИТУЛКУ. ПИСАР ЗАХІДНИХ ВОРІТ ПРИТУЛКУ»
}

\begin{abstract}
Анотація. Статтю присвячено оригінальному трактуванню проблемі місця в українській літературі. Увагу зосереджено на понятті сакрального простору, сакрального ландшафту геопоетичних особливостях художнього світу інтелектуального роману. Об’ект дослідження - постмодерний твір Г. Пагутяк, де в контексті феномену утопічного Притулку письменниця подае власне бачення цивілізаційних проблем, частина з яких пов'язана із втратою суспільством духовності. З'ясовано, що у творі Г. Пагутяк відбуваеться модифікація традиційних сакральних локусів. Переосмислення класичної моделі такого простору мотивовано динамікою рецепції згаданих інституцій, рефлексій над їхнім призначенням. Доведено, що авторка відводить роль оновленого сакрального ландшафту саме Бібліотекам як місцю, що здатне спонукати до пізнання власної душі.
\end{abstract}

Ключові слова: геопоетика, топос, утопія, сакральний ландшафт, неоміфологізм.

Kocherha Svitlana, Havryliuk Olha National University of Ostroh Academy

\section{MODIFICATION OF THE TRADITIONAL SACRED SPACE IN THE DILOGY OF H. PAHUTYAK «SCRIBE OF THE EASTERN GATE OF THE ASYLUM. SCRIBE OF THE WESTERN GATE OF THE ASYLUM"}

Summary. The article considers the problem of space in the literature. In particular, attention is focused on the theme of sacred space. It has been found that this is a problem of interdisciplinary level, so it requires the involvement of knowledge from other sciences, especially geography. Thus, the concept of the sacred landscape was identified as one that accumulates all the features of the subject of study. The difference between the concepts of «religious» and «sacred» is also substantiated. The object of research was chosen postmodern work of modern writer H. Pahutyak - «Scribe of the Eastern Gate of the Asylum. Scribe of the Western Gate of the Asylum». Based on her own neomythological thinking, the author creates a utopian world of Asylum, a place that represents absolute protection for all the disadvantaged. Therefore, there are many sacred landscapes in the geographical space of this place, we have identified the main sacred topos. Most of them are temples, monasteries, or their ruins, as well as some natural landscapes. These places have their own history and are important not only for the characters they are associated with, but also for the structure of the fictional world as a whole. In the course of our research, we found out that the inner essence of the characters is revealed precisely when they collide with the sacred space. Thus, the mentioned loci appears as metaphors rather than real places, like the whole world of the Asylum in general. It is proved that in H. Pahutyak's novel there is a desecration of traditional models of spiritual space. They are unable to fulfill their ideal purpose for a number of reasons, which is why the world of Asylum arises in opposition to them. While creating the image of sanctuaries, the author rethinks classical images and motifs. In this way, the writer demonstrates her own vision of human development on the spiritual path. In the space of the Asylum, the role of the sacred landscape is taken over by Libraries as a space that is able to go beyond human ideas and laws. H. Pahutyak continues the literary tradition of depicting the library-labyrinth as a container of secret knowledge. However, within the Asylum, this image is given a new meaning, namely the labyrinth of human consciousness, falling into which the individual is able to begin to comprehend his own being. Thus, the writer prioritizes in the spiritual life of human his ability to self-knowledge and self-acceptance.

Keywords: geopoetics, topos, utopia, sacred landscape, neomythologism.

$\Pi^{2}$ остановка проблеми. Духовний простір людини, їі внутрішні інтенції, світосприйняття, сакральний світ завжди були об'єктом зацікавлення багатьох наук: природничих, соціальних i, безумовно, гуманітарних. На сьогодні неможливо говорити про сучасні студії художньої літератури без різноманітних досліджень сакральних елементів у цій галузі, серед яких вивчення певних релігійних начал, сакруму в словесності тощо. Один із дослідників цієї категорії в письменстві, I. Набитович, зазначає, що «пошук виявів sacrum'у в художній літературі здійснюеться через інтерпретаційно-герменевтичні окреслення характеристик сакрального часу та священного простору (сакрохронотопу), виявлення ієрофраній, теофаній, через аналіз структурних компонентів релігійної символіки, в описі обрядових ритуалів та у відчитанні й дескрипції мітологічних структур - опираючись на релігійно марковані конщепти» [7, с. 30]. Власне простір постає однією із ключових ланок у дослідженні духовного начала в текстах.

Аналіз останніх досліджень і публікацій. Термін «сакральний», який походить від латинського «sacrum", означає «священна річ, дія». Це поняття пов'язане із системою знань про священні об'єкти й має безпосереднє відношення насамперед до релігійного культу, що засвідчено аналізом різноманітних наукових джерел із фрілософріï, соціології, також географріi. Проте все ж існує й інший погляд на цю проблему. Одним із перших дослідників, який розмежував сакральне від релігієзнавчого був М. Мосс. На думку науковця, «сакральні дії - це не релігійні дії. 
Це просто особливі дії, яким ми приписуємо властивість "незвичайності"» [5, с. 76]. О. Міщенко слушно розвиває цю думку, наголошуючи, що поняття «сакральний» $є$ радше світоглядною категорією, котра «надає людям, діям, території та іншим об'єктам такої властивості, яка відокремлює їх від профранного та ставить у положення виняткової цінності, значущості й на цій підставі потребуе виняткового ставлення» [4, с. 84]. 3 погляду П. Трусона, сакральне перевершує релігійне вже тим, що весь акт людського життя сам по собі є сакральною цінністю [10].

У літературі поняття сакрального вважають центральною категорією сві-товідчування, що виражає буття-у-світі, відтак розглядають як певну універсалію, що містить у собі не так концепти різних релігій, як концепти культури загалом. Сучасне літературознавство запропронувало низку шляхів для дослідження сакрального в тексті на різних типологічних рівнях: «1) на генологічному (родів, жанрів), морфологічному (структури твору, її трансформації, архітектоніки, інтертекстуальності та глокалізму); 2) на тематологічному (тем, сюжетів, мотивів, фрабул); 3) на рівні літературних епох, течій, напрямків, стилів та ідіостилів, поетики» [11, с. 98]. Пошуки в цьому напрямку неможливі без аналізу й інтерпретації тих частин сакрального, які стосуються простору, адже індивід, пізнаючи світ, прагне віднайти своє місце в ньому, ідентифрікувати себе в універсумі, тобто співвіднести людське життя із сакральним буттям.

Дослідженням сакрального простору передусім займається сакральна географія. Вагомими працями стали роботи К. Парка, В. Воловика, О. Міщенко. Об'єктом цієї науки вважають саму людину, її сакральний світ, культові місця, природне й соціальне середовище. Проте аналіз останніх досліджень і публікащій доводить, що сакральний ландшафт є поняттям міждисциплінарним, його можна вивчати не лише в рамках географріï, а й фрілософіiі, антропології, культурології, літературі тощо.

Виділення невирішених раніше частин загальної проблеми. В українському літературознавстві проблему простору у творах почали розглядати відносно недавно, тому залишається чимало невисвітлених аспектів. Малодослідженою залишається, зокрема, й проблема сакрального простору.

Серед сучасних письменників, які у своїй творчості зверталися до цих мотивів, можна виокремити Г. Пагутяк. У художній прозі письменниці поєднуються авторське світобачення, міротворчість й переосмислення класичних міфрів, архетипів, образів тощо. Оригінальність міфомислення Г. Пагутяк полягає у використанні нею своєрідної бінарної аксіології, в якій особливе місце займає протиставлення сакрального й профранного; контамінація християнського світогляду 3 пантеїзмом також $є$ вагомим чинником у творенні часопростору вигаданого світу. Творчість письменниці досліджували В. Агеєва, I. Біла, Г. Бошкань, В. Габор, М. Жулинський, О. Поліщук, Н. Синицька, Т. Тебешевська-Качак та ін., однак переважно їхні праці стосувалися жанрово-стильових ознак доробку авторки, інтелектуальності й інтертекстуальності творів, неоміфологічних аспектів прози. Нині вважаємо актуальною проблему дослідження оригінальної репрезентації простору у творчості письменниці.

Мета статті - з'ясувати особливості авторської інтерпретації сакрального простору в дилогії Г. Пагутяк «Писар Східних Воріт Притулку», «Писар Західних Воріт Притулку».

Виклад основного матеріалу дослідження. Дилогія «Писар Східних Воріт Притулку», «Писар Західних Воріт Притулку» є яскравим зразком авторської dpiлософрії Г. Пагутяк. У творі наявна чимала кількість алюзій пов'язаних із християнським космологічним міфом, проте письменниця застосовує тут притаманний для неоміфрологізму прийом десакралізації. У контексті вигаданого авторкою світу відбувається переосмислення традиційних цінностей, Г. Пагутяк розвиває мотив духовної кризи сучасної цивілізації насамперед через рух персонажів у просторі, їхнього зіткнення із різноманітними локусами, значну частину яких можна окреслити як сакральні. Варто зазначити, що ми розмежовуємо сакральний простір на природній (річки, водні джерела, озера, дерева, гаї, садки тощо) та культурний (архітектурні споруди, сакральні комплекси). Однозначно, що велика частка сакрального простору, зазвичай, належить релігійним об'єктам, хоча не варто забувати про символізацію і міфр, які надають ландшафрту ціннісного значення, будь-яке місце потенційно священне й може стати сакральним на певному етапі своєї історії.

Значна роль у візії простору належить сакральному ландшафртові, що акумулюе в собі різні аспекти тлумачення його винятковості. Серед різноманіття визначень, на нашу думку, переконливим видається узагальнення О. Міщенко, яка вважає, що «сакральний ландшафт - це природна, природно-антропогенна чи антропогенна система, сформована в результаті взаємодії природи та людини, пов'язана із певними життєвими символами, міфрами, вагомими подіями, релігійними почуттями та має надзвичайно ціннісне значення для людини або групи людей та потребує особливого вшанування та охорони» [4, с. 85].

У дилогії «Писар Східних Воріт Притулку. Писар Західних Воріт Притулку» представлено чимало як природних, так і культурних сакральних просторів. У творі Г. Пагутяк можемо віднайти проекції різноманітних духовних площин, у його художньому світі тісно переплелися ідеї християнства, буддизму та язичництва. Яскравим сакральним об'єктом, на прикладі якого в тексті проявлена східна фрілософрія і східне бачення світу, можна вважати озеро Симеона. Сам герой нагадує мудреця, відлюдника, основою поведінки якого $є$ урівноваження власних почуттів, обмеження бажань, прагнення до спокою, що цілком суголосно положенням східних учень. Цю констатацію підтверджує містичний зв'язок героя із водою: «Симеон був відлюдником, однак приемним і приязним. Якщо він не хотів нікого бачити, то випливав на середину озера і слухав тишу. Иого душа наповнювалась небом, і тоді вже ні для чого не залишалось місця» [8, с. 52]. Таке трактування далеко не нове, адже вода у різних культурах традиційно асоціюеться 3 потужною символікою прадавніх часів, проте саме річки $\epsilon$ важливою частиною міфрологічної географрії. 
Натомість Г. Пагутяк у своему космологічному неоміді про Притулок виводить саме образ озе$\mathrm{pa}$, протиставляючи його таким чином традиційним топосам: «Тут не тече ріка Лета, у водах якої з тебе змиваються всі гріхи й доброчинства. Річок тут мало» [8, с. 103]. Озеро постае для Симеона індивідуальним сакральним ландшафтом, адже має ціннісне значення лише для нього, саме він визначае святість цього місця.

Подібним локальним сакральним ландшафтом можна назвати пагорб Джона Сміта. Варто зазначити, що це місце має давню історію й виникло спершу як святилище невідомого бога. Пізніше пагорб набувае сакрального значення для чернця, що прибув із "того світу». Саме він почав будувати тут капличку, яка через певний час була забута й занепала. Згодом, керуючись власними духовними переживаннями й пошуками, сюди приходить Джон Сміт: «Розсуваючи бузину й кропиву, Сміт увійшов між рештки стін. Даху не було, але липа з її широким листям могла ним бути, і він упізнав це місце - воно було його» [9, с. 28]. Уподібнюючись Сізіфу, Джон Сміт щодня, піднімаючись на пагорб, носив туди каміння. Проте це заняття не було справжньою роботою, лише черговою втечею героя від себе, бо «справжня робота відбувалась у душі. Вона полягала в тому, щоб, залікувавши рани, приспавши біль, знайти единий шлях, який допоможе повернутись у той світ, хоч ти йому не потрібний» [9, с. 126]. Каплиця стала своерідним симулякром, що відмежовував Джона Сміта від прийняття самого себе. Проте згодом герой переосмислюе свої дії, усвідомлюючи, що дім, який він намагався збудувати для своєї матері, образ якої вбачав у намальованій Мадонні, не міг стати справжнім прихистком: «Я хотів руками вбивці збудувати дім. У тому світі будинки будують ще гірші за мене, але тут не можна так будувати. Єдиний дім, у якому ти могла б оселитися, це моє серце» [9, с. 135]. Сам пагорб же нагадуе героєві моменти "коли він утікав у гори від п'яного батька» $[9$, с. 136]. Отож причиною сакралізації гори Джоном Смітом було як і його травматичне дитинство, так і дорослий досвід вбивці. Намагаючись відновити щось зруйноване, він виконував марну, Сізіфову працю. I лише прийнявши себе зі своїм минулим, він зміг зійти вниз та йти власним шляхом без страху й сумнівів.

Поривання героя відшукати сакральне місце можна пояснити тим, що для індивіда на рівні із необхідності їжі й безпеки постае потреба закріпитися в просторі, облаштувати певне місцеорієнтир в «центрі світу». Будь-яка сакралізація зазвичай пов'язана із пошуком центру, ядра, проте в утопічному просторі Притулку Г. Пагутяк не діють традиційні закони й уявлення. Супроти класичної трирівневої моделі світобудови, що містить у собі світ підземний, серединний і небо, ієрархія Притулку є радше горизонтальною, а основні точки ціеї вісі зосереджені саме на вході й виході зі світу, тобто в цьому просторі, на відміну від традиційних космогоній, відсутній сакральний центр, а відтак будь-яка спроба створити тут аналог земного храму як уособлення цього центру закінчуеться невдачею. Від цих споруд в Притулку залишилися самі руїни, бо «навіщо Притулкові марнославні палаци, які не додають людині гідності, а роблять її рабом?» [9, с. 125]. Такі монастирі чи храми-притулки постають псевдоприхистками, не здатними насправді захистити тих, хто цього потребуе.

У дилогії наведено історії людей, що зверталися до храму, але не отримали відгуку. Приміром, у «Писарі Східних Воріт Притулку» показовою є розповідь від імені чернця Себастіяна. Він разом з іншими братами зачинив двері свого монастиря перед людьми: «Випав сніг і вкрив останки тих, хто марно благав у нас притулку, але такою великою була сила закону, що ніхто не посмів відчинити брами» [9, с. 32]. Храм не спромігся захистити людей від неврожаю, війни, мору - всього, що убивае людей за його мурами. у «Писарі Західних Воріт Притулку» оповідаеться історія про хлопця, який утік із дому, аби не потрапити до монастиря. У цьому випадку сакральний ландшафт відіграє роль своерідної в'язниці, адже героя туди відправляють примусово, аби не ділити спадок між ним і старшим братом. Зміну традиційної ролі монастиря як дому Бога чітко простежуемо в порівнянні із закинутим приміщенням церкви: «Тут, у забутій людьми, але не Богом, церковці, їх оточувало невидиме коло безпеки, бо храми завжди мали право Притулку» [8, с. 65-66]. Як бачимо, авторка свідома ідеального призначення храму, проте свою місію він виконуе не завжди, зокрема у твоpi наведено категорії людей, яким було заборонено вхід до монастиря (іновірці, християни-некатолики тощо), отож він не відповідае критеріям абсолютного прихистку. Г. Пагутяк постулюе думку, що віра чи Бог не потребують стін, часто навпаки - відкритого простору: «Так виходить, що тільки в хащах можна стати святим, а в місті, чи монастирі - годі» [8, с. 89].

На теренах Притулку залишився лише один монастир, який спершу хибно можна сприйняти за сакральний центр, проте варто враховувати, що топос Притулку е трансформацією звичних уявлень про місце-прихисток як храм чи рай. Віра в існування "цього світу» стае альтернативою до традиційних релігій, тому «монастир як варіант храму позбавлений функції центру, а є лише однією з частин Притулку» [2, с. 137]. Навіть зовнішній вигляд цього сакрального ландшафрту не відповідае певним канонам, письменниця називае Монастир островом посеред Притулку; оточений лісом і дерев'яним парканом, він нагадуе радше дерев'яну фортецю. Внутрішній устрій також відрізняеться від уявлень, освячених традиціями, адже типова простора кімната не нагадувала помешкання самітника, що е ще одним підтвердженням художньої концепції авторки - Монастир у Притулку перестав виконувати функщії дому Господа. Колись це було місце для тих, хто «ототожнював власні страждання зі стражданнями Бога, якого розіп'яли на хресті» [9, с. 102], але згодом сама ідея Бога пережила зміни, оскільки «не було такої людини, яка б хоч раз іiї не зрадила, засумнівавшись в існуванні Всевишнього, який мае людську подобу. Здебільшого в Монастирі нині оселялися ті, хто зрадив Бога і не міг позбутися докорів сумління» [9, с. 103]. Водночас $\Gamma$. Пагутяк трансформуе засади храму: у Притулку він не є осердям ідолів, у ньому немає потреби читати священні книги чи молитви, вони тут за- 
йві, позаяк кожен є сам собі молитвою. Монастир $\epsilon$ прообразом прихистку, він захищає людину від інших людей, однак, зазначає авторка, «відмовитися від себе, померти за життя, замурувавшись у стінах, покластися на милість Не-видимого, Грізного і Милосердного - не кожен на це здатний. Як можна відмовитися від себе, не знаючи, від чого ти відмовляешся, - тобто, не пізнавши себе?» [9, с. 68]. Тут мешканщі шукають не спасіння, а безпеки, вони проходять не шлях каяття, а шлях самопізнання, бо «щоб почуватися справді в безпеці, потрібно оновити кожну клітинку свого тіла, щоб тебе ніхто не впізнав у тому світі й не повернув знову в рабство» [9, с. 124].

Освоення Антоном простору під час своєї подорожі могло б нагадувати паломництво, своєрідний похід до святого місця, де герой міг би віднайти внутрішній спокій, проте Писар «шукав не Монастир, а Генріха на прізвисько Кухар» [9, с. 102]. I саме він, звичайна людина, допомагає Антонові. Зрештою, втрату храмом своєї сакральної фрункції переконливо доводить закінчення першої книги. В останній повіданій прибульцем історії фрігурують золоті двері, за якими людські душі знаходять собі обитель, але вона не стає магнетичним абсолютом. Т. Юр'єва, з'ясовуючи суть ієротопії, згадуе традицію будування Золотих воріт в Киеві, Володимирі, маючи за прототип такі ворота в Константинополі, які, своєю чергою, були створені за образом Золотих воріт Срусалима [12, с. 168]. Можна вважати, що золоті двері є близьким символом до Золотих воріт, які, за християнськими уявленнями, мають слугувати для приходу Господа. Проте герой оповіді відмовляється увійти в них, бо не хоче розлучатися зі своєю душею - «ану ж, вона не зможе з іншими душами, і їі там битимуть?» [8, с. 135]. Цим фріналом авторка наголошуе, що для мешканщів Притулку не притаманне виокремлення божественної суті, вони мають ̈̈ у собі, але ніколи не уявляють ï поза чи над собою. Від храмів тут лишилися руїни, бо цей цикл цивілізащійного поступу вичерпав себе. Натомість у дилогії сакральну функцію на себе перебирають Бібліотеки.

У сучасній літературі образ бібліотеки має метафоричне й стилістичне навантаження, відображає проблеми та кризи певних світоглядів. Німецький дослідник мотиву бібліотеки Д. Pirep окреслює його семантичне поле сукупністю людського знання, індивідуальним чи колективне ставлення до цього знання. Бібліотека зазвичай уособлюе людський досвід, пам'ять, підтримуе рівновагу між спогадом та забуванням, це місце зустрічі минулого з теперішнім в акті читання тощо [13, с. 18-19]. Цей образ не є новим для літератури. У 1941 році Х. Борхес створив знакове оповідання "Вавилонська бібліотека", згодом подібні мотиви використовуюють У. Еко в романі «Ім'я троянди», Т. Пратчетт в серії романів про «Плаский світ» тощо. Закономірно, що образ бібліотеки «як величезного зібрання незліченних рядів книжок, текстів, сторінок, рядків на цих сторінках, букв, ідей та історій, сюжетів, які, мандруючи 3 книжки у книжку, отримують найрізноманітніші розв'язки та розгалуження, неодмінно мусив уподібнитися до лабіринту, сказати б, метафоризуватися у напрямку ідеї лабіринту» [6, с. 46]. Своєю чергою, концепт лабіринту містить у собі ряд ознак, які є водночас притаманними для категорії сакрум, насамперед це передчуття таємниці, аура захоплення й притяжіння. Функція лабіринту як сакрального локусу пов'язана 3 ідеєю охорони певного центру, захисту чогось цінного, а вхід до лабіринту був рівнозначний до ініціації. Щодо центру, то лабіринт міг захищати найрізноманітніші речі, але найважливішим $\epsilon$ захист магічно-релігійного простору, який мав залишатися недосяжним для непосвячених. Відповідно бібліотека як окремий лабіринт-всесвіт перебирає на себе ознаки сакрального, стає символічним мікрокосмосом.

Г. Пагутяк, як і Х. Борхес та У. Еко, створює в межах свого художнього світу бібліотеку-лабіринт, що набуває ознак сакрального простору і $є$ третім світом на рівні зі світом Притулку й «тим світом». Бібліотек у творі дві, вони розміщені на вході до Притулку й на виході, у просторі прихистку вони постають не просто місцем для зберігання книг, а своерідним храмом знань. Водночас Бібліотеки - це своєрідна ланка, що з'єднує Притулок і засвіття, «книги 3 магічної бібліотеки можуть стати дірою, проломом у той світ, і врешті втягнуть туди на поталу сум'яттю, зневірі, сумнівам» [8, с. 62], відтак поводитися із ними потрібно вкрай обережно. Проникнення в Бібліотеку, як у сакральний локус, несе в собі небезпеку зустрічі індивіда із сакрумом, що для непідготовленої людини може викликати бурю почуттів, безсоння, розтривожити незагоєні рани чи боляче вдарити.

Бібліотеки стають одним із прикладів фрункціювання гіпертексту, адже книги в них не піддаються систематизації, у цьому просторі не існуе двох однакових творів, а пізнавати тексти можна із будь-якої полиці. Писар Яків порівнюе книгозбірню із живою істотою, довіру якої необхідно заслужити: «Бібліотека сама знала, що йому потрібно. Він мав підійти й взяти книжку і виявлялось, що саме вона відповідає потребам його душі» [8, с. 38]. Семантичний образ цих книгозбірень набуває містичного забарвлення, адже видання, які тут зберігалися, не мають авторів, вони самі себе створюють. Авторка порівнюе книги із прибульцями, адже вони теж потребували опіки, не лише фрізичної, на кшталт захисту від вологи, мишей, із ними потрібно було розмовляти, щоб вони не почували себе самотніми.

Бібліотека існує у просторі Притулку з метою застерегти від повторення помилок, змусити «ледачий розум осягнути дивні зв'язки між речами й людь-ми, цілковито зневажаючи простір і час» [8, с. 420]. Бібліотека біля Східних Воріт не могла дати відповіді на жодне із важливих питань, до неї рідко захо-дили відвідувачі, бо «той, хто уникає спогадів про минуле, намагається відгородитися від того, що може розтривожити ще незагоєні рани» [9, с. 21]. Натомість Бібліотека біля виходу наділена здатністю добирати книгу для прибульця, вирішити, яку істину йому відкрити, таким чином переносячи акцент «з ідеї формулювання істини на ідею пошуку істини» [1, с. 86]. Зважаючи на ці відмінності, подорож мешканців від одніеї Бібліотеки до іншої, нагадуе паломництво більше, ніж шлях Антона до Монастиря. 3 ціеї причини первісно сторінки в книгах обох Бібліотек не містять нічого, вони порожні допоки читач, який розгорне книгу, не буде готовий їі 
зрозуміти. Таким чином відбувається реалізація герменевтичного принципу: текст набуває сенсу лише в руках читача, у діалозі із ним, бо саме читачі надають книгам значення, транслюючи на письмо власні спогади, переживання, думки, адже книги «нічого не пояснюють 3 того, що ми можемо пояснити самі» [8, с. 123].

Бібліотеки у творі Г. Пагутяк перебирають на себе сакральну фрункцію, адже здатні вийти за межі усталених людських законів, навіть змінити долю людини чи долю цілих народів. Разом 3 тим цей простір сповна непідвладний людям, бо книги у ньому не просто джерело мудрості, це, насамперед, засіб пізнання себе. Тi, хто зможуть осягнути простір бібліотеки-лабіринту, стають мудрішими не завдяки банальним істинам, чи чужому досвіду, а завдяки собі, бо блукання стінами лабіринту - це блукання лабіринтами своєї свідомості. Бібліотека в дилогії стає частиною сакрального ландшафту, здатною до регенеращії, акумулює в собі ідею вічного повернення й повторення, а книги разом із історіями, вміщеними в них, набувають ознак серцевини сакрального простору, в якому прихованні незбагненні таємниці.

Висновки. Отже, в дилогії Г. Пагутяк представлено чималий спектр сакральних ландшафтів, культурних і природніх. Кожний локус цього простору фрункційно пов'язаний із трансформаційними процесами у становленні особис-тості мешканців Притулку. Письменниця подає в ро- мані власне розуміння сак-рального, що певною мірою суперечить традиційним уявленням. Особливу увагу Г. Пагутяк приділяе озеру Симеона й горі Джона Сміта, адже згідно із авторською світоглядною концепцією істинна духовність виникає внаслідок кореляції людини із природнім началом. Культові споруди, храми не витримують перевірки часом - ні фрізичної, ні метафізичної, тому в просторі Притулку вони існують лише у вигляді руїн. Топос Монастиря, попри стереотипні очікування, не має нічого спільного із церковними інституціями, він виникає радше як альтернатива їм. Натомість письменниця творить новий сакральний простір центральна позицію в якому належить Бібліотекам.

Г. Пагутяк, відповідно до світових традищій, розгортає ідею бібліотеки як лабіринту, вмістилища знань і пам'яті, проте авторка доповнює цей образ. Книгозбірні у творі набувають певного ініціального значення. Знання у них не $є$ доступними для всіх і потребують залучення досвіду потенційного читача. Готовність до прочитання книги співвіднесена із готовністю прийняти себе, своїх власних відповідей на вічні питання. Сакральність цього простору полягає в потенційній самодостатності віри, що не має релігійного забарвлення, але здатна скеровувати мешканців Притулку на шлях самопізнання. Таким чином письменниця впроваджує ідею духовності, що живе в надрах підсвідомого й не потребуе фрізичного втілення.

\section{Список літератури:}

1. Біла І. Інтертекстуальність роману Писар Західних Воріт Притулку Галини Пагутяк. Slavica Wratislaviensia. 2010. Vol. 152. P. 81-87.

2. Бошкань Г. І. Неоміфологізм у художній прозі Галини Пагутяк : дис. ... канд. фрілологічних наук : 10.01 .01$. Київ, 2017. 237 с.

3. Міщенко О. Сакральний ландшафт: зміст і функції. Вісник нац. ун-ту іл. Т. Шевченка. Географбія. 2018. № $1(70)$. C. $83-88$.

4. Мосс М. Общества. Обмен. Личность. Труды по социальной антропологии. Москва : Книжный Дом «Университет», 2011. $416 \mathrm{c.}$

5. Набитович I. Концепт лабіринту як сакрального локусу (На прикладі новелістики Х. Борхеса, романів У. Еко «Ім’я рози» та К. Мосс «Лабіринт»). Магістеріул. Літературознавчі студії. Київ : Нац. ун-т «Киево-Могилянська академія», 2010. Вип. 38. С. 45-51.

6. Набитович I. Категорія sacrum і художня література. Слово $i$ Чac. 2009. № 6. С. 27-39.

7. Пагутяк Г. Писар Західних Воріт Притулку. Львів : ЛА «Піраміда», 2011. 136 с.

8. Пагутяк Г. Писар Східних Воріт Притулку. Львів : ЛА «Піраміда», 2011. 140 с.

9. Труссон П. Сакральное и миф. Internet archive: Wayback Machine : вебсайт. URL: https://web.archive.org/ web/20170614120509/http://nationalism.org/vvv/trusson-sacral-and-myth.htm (дата звернення 21.03.2021).

10. Чобанюк М. Проблема дефініції сакрального в епоху постмодернізму. Наукові праці Чорнолорського державного університету імені Петра Могили колплексу "Киево-Могилянська академія". 2013. Т. 217. Вип. 205. С. 97-99.

11. Юрьева Т. Метагеография и иеротопия: категория пространства в средневековой культуре. Верхневолжский филологический вестник. 2015. № 3. С. 163-170.

12. Rieger D. Imaginäre Bibliotheken: Bücherwelten in der Literatur. München : Fink, 2002. 389 p.

\section{References:}

13. Bila I. (2010) Intertekstualnist romanu Pysar Zakhidnykh Vorit Prytulku Halyny Pahutyak [Intertextuality of the novel Scribe of the Western Gate of the Asylum by Halyna Pahutyak]. Slavica Wratislaviensia, vol. 152, pp. 81-87.

14. Boshkan H. I. (2017) Neomifolohizm u xudozhnij prozi Halyny Pahutyak [Neomythologism in the fiction of Halyna Pahutyak]. (PhD Thesis), Kyiv.

15. Mishchenko O. Sakralnyy landshaft: zmist i funktsiyi [Sacred landscape: content and functions]. Visnyk nats. un-tu im. T. Shevchenka. Heohrafiya, no. 1(70), pp. 83-88.

16. Moss M. (2011) Obshchestva. Obmen. Lichnost. Trudy po sotsialnoy antropologii [Society. Exchange. Personality. Works on social anthropology]. Moscow: Knizhnyy Dom «Universitet». (in Russian)

17. Nabytovych I. (2010) Kontsept labiryntu yak sakralnoho lokusu (Na prykladi novelistyky KH. Borkhesa, romaniv U. Eko "Imya rozy» ta K. Moss "Labirynt») [The concept of the labyrinth as a sacred locus (On the example of short stories by H. Borges, novels by U. Eco «The Name of the Rose» and K. Moss «Labyrinth»)]. Magisterium. Literaturoznavchi studiyi, vol. 38, pp. 42-51.

18. Nabytovych I. (2009) Katehoriya sacrum i khudozhnya literatura [Category sacrum and fiction]. Slovo $i$ Chas, no. 6 , pp. 27-39. 
19. Pahutyak H. (2011) Pysar Zakhidnykh Vorit Prytulku [Scribe of the Western Gate of the Asylum]. Lviv: LA «Piramida». (in Ukrainian)

20. Pahutyak H. (2011) Pysar Skhidnykh Vorit Prytulku [Scribe of the Eastern Gate of the Asylum]. Lviv: LA «Piramida». (in Ukrainian)

21. Trusson P. Sakral'noye i mif [Trusson P. Sakral'noye i mif]. Internet archive: Wayback Machine. Available at: https://web.archive.org/web/20170614120509/http://nationalism.org/vvv/trusson-sacral-and-myth.htm (accessed 21 March 2021).

22. Chobanyuk M. (2013) Problema definitsiyi sakralnoho v epokhu postmodernizmu [The problem of defining the sacred in the era of postmodernism]. Naukovi pratsi Chornomorskoho derzhavnoho universytetu imeni Petra Mohyly kompleksu "Kyyevo-Mohylyanska akademiya», vol. 217, no. 205, pp. 97-99.

23. Yuryeva T. (2015) Metageografiya i iyerotopiya: kategoriya prostranstva v srednevekovoy kulture [Metageography and hierotopy: the category of space in medieval culture]. Verkhnevolzhskiy filologicheskiy vestnik, no. 3, pp. 163-170.

24. Rieger D. (2002) Imaginäre Bibliotheken: Bücherwelten in der Literatur. München: Fink, 389 p. 